\title{
THE EFFORT TO IMPROVE TEACHERS'PERFORMANCE OF SMA TMI ROUDLATUL QUR'AN IN COMPOSING LESSON PLAN AND EVALUATION INSTRUMENT OF CHARACTER EDUCATION THROUGH WORKSHOP ACADEMIC YEAR 2015/2016
}

\author{
By \\ BUDI RAHARJO \\ A Supervisor of Senior High School at Metro Municipal City \\ e-mail :budiraharjo_1406@yahoo.com
}

Abstract:

Difficulties found in Senior High School (SMA) TMI Roudlatul Qur'an, teachers were not able to integrate character value into their lesson plan and to identify which behaviour must be success indicators of character education. Out of 18 Character value existed, the measurement of students'success as the better change of their behaviour, some only covering observation and lack of triangulation consideration to more accountable result. Worskhop potentially becomes one of the ways to up grade teachers'performance in determining the instrument of character value education, at the same time, train them the way composing lesson plan which integrates character education. This school action research was aimed to carry out workshop at SMA TMI Roudlatul Qur'an of Metro Municipal City, to improve teachers'performance in composing evaluation instrumen of value character education, to improve teachers'performance in composing integrated character value education. The research took place at SMA TMI Roudlatul Qur'an, located at Mulyojati, Metro Barat, Metro Municipal City. It was done in odd semester, continually to one month. Started in early Academic Year 2015/2016, July to August. The researcher concluded that teachers of SMA TMI Roudlatul Qur'an improved their performance well in composing evaluation instrument of value character education and integrated value character lesson plan through workshop. Facts: Workshop process was considered fair 11 teachers, good by 16 teachers, and very good by 12 teachers. At cycle II, the performance of composing evaluation instrument of character education showed 11 teachers were less sufficient performance, 16 teachers were good performance, and 12 teachers were very good. And the performance of composing integrated character value at cycle II showed 8 moderate teachers, 19 good teachers, and 12 excellent teachers.

Key words: Workshop, Lesson Plan, Character Education Evaluation

\section{A. Introduction}

To know the output of an instructional process which involves students can be done in many ways, one of them by using tests with certain standard and the development. Educators must be familiar to many techniques required to evaluate their students, how far the learning materials have been accomplished by the students. One of measurement concepts to a competency mastery after learning proces is Criterion Base Measurement (known as PAP). To determine the criterion of each indicator mastery, basic competency mastery, competency standard mastery, and character value education, teachers must be able determine which instrument should be applied to evaluate character education. 
The set of evaluation instrument for character education is a preliminary step of evaluation education in the implementation of School Base Curriculum (named as KTSP) in SMA TMI Roudlatul Qur'an. It is because this school proposes character value as their feature of education. Competency based curriculum applies criterion base evaluation require educators and the school to set character education evaluation through an analysis and certain mechanism, character education evaluation procedure. Teachers of SMA TMI Roudlatul Qur'an must master the procedure to establish comprehensive evaluation.

The fact at SMA TMI Roudlatul Qur'an found that most of the teachers did not apply certain procedure required.. Instrument of character education evaluation did not meet analysis and deevelopment principle. The instruments mostly used spontaneously without sufficient consideration to related variable along with the indicators of character education feature brought by SMA TMI Roudlatul Qur'an. An activity in the beggining of academic year became a proper event to share valuable information to all teachers of how to composecharacter education evaluation instrument as a legitimate instrument of character education evaluation to all subjects in the school

Trouble mostly found in SMA TMI Roudlatul Qur'an, the teachers were not able to integrate the character value into their lesson plan, and to identify related indicators as indication of success in character education. Out of 18 character value existed, only a few of them were measured to know which students behaviour changed better through observation aspect. The measurement did not apply tringulation for thrustwhorty data. In house training or workshop became one of the ways to ugrade teachers'performance in seeting evaluation instrument of character education and character value integrated lesson plan at SMA TMI Roudlatul Qur'an.

Considering the background, this school action research meant to carry out workshop at SMA TMI Roudlatul Qur'an, to improve teachers'performance in composing instrument of character education, and to improve their performance in composing character value integrated lesson plan.

\section{B. Research Method}

School action research is a cyclical treatment. Each cycle consist of (1) 
planning, (2) acting, (3) observing, (4) Qur'an is located at Mulyojati of West reflecting,(Kemmis, \& McTaggart, 1983). Metro district, Metro Municipal City. Done

Supervision intensity done with various technique. Planning the treatment of each cycle consider time availability, eventhough research duration is not limmited, it is limmited by the success indicators of the research. As previously mentioned, comprehensively the supervision concept is instruction supervision, furtherly, instruction supervision is divided into several approaches, they are 1) gouping technique, 2) individual technique. The difference treatment of each cycle can be made based on the use of the two technique one after another. The technique used in the first cycle was grouping technique, and the second cycle used individual technique. Another alternative can be used is, in case success indicators are not achieved after the second cycle, interchangably use of the two technique.

\section{Subject, Object, Location, and}

\section{Research Time}

Subjects of the research were the teachers of SMA TMI Roudlatul Qur'an, Academic Year 2015/2016. There were many 39 teachers involved from all classes. Object of the research were the teachers'performance and how well the workshop organized. SMA TMI Roudlatul in odd semester, continually held in one month. It was earlier in July to August of Academic Year 2015/2016.

\section{Procedure of The Research}

Steps done by supervisor

duringsupervision schedule were:

1) Setting measurement basis, this was to set bench mark to follow. This step done by doing a mesurement of teachers'performance in composing evaluation instument of character education before the treatment given. Data obtained from the measurement then analyzed to accentuate which aspects need to improve. The schedule of meeting the teachers was set through a coordination with the principal of SMA TMI Roudlatul Qur'an.

2) Evaluating, this was done by crosschecking the instrument made by the teachers. Evaluation carried out after the teachers were treated with several techniques.

3) Comparing data of measurement to a bench mark need to achieve. Based on this comparison result, next step then formulated. 
4) Filing misbehaviour and error should have occured. This is done by isolating performance aspects need to improve with different technique.

5) Conducting collective action, to enginer what already planned to come true.

The first supervision was done in the first week of workshop program. Next workshop was done after a week interval. During the interval, the teachers were meant to amend their instrument of evaluation and integrated lesson plan. The obervation of workshop progress was conducted by peer supervisor.

Observation conducted by peer supervisor aimed to monitor the implementation steps of supervision technique, both grouping and individual when the workshop was in progress. The observation may reveal some error steps made by the researchers which need to improve later at second cycle of the treatment. By having peer supervision, the research could make sure whether the implement went in the proper way.

All files and papers related to the observation during the implementation of the supervision technique, were collected and then analyzed thoroughly with peer. The data then, both quantitative and qualitative, used as reflection materials.

\section{Duration of Treatment and Success} Indicators

Success indicators were formulated to help seeing the objectives achievement made by the researcher. Success indicators can be seen on the table below here.

TableDuration and Success Indicators of The Research

\begin{tabular}{|c|l|l|l|}
\hline Duration & \multicolumn{1}{|c|}{$\begin{array}{c}\text { Aspectsof Research } \\
\text { Objectives }\end{array}$} & \multicolumn{1}{c|}{ Success Indicators } & \multicolumn{1}{c|}{ Max } \\
\hline 4meetings & 1) Workshop & 1) Reaching good \\
Implemtation & $\begin{array}{l}\text { predicate } \\
\text { 2) Teachers'performance } \\
\text { 2) }\end{array}$ & $\begin{array}{l}\text { Reaching good of entire } \\
\text { predicate }\end{array}$ & $\begin{array}{l}\text { workshop steps } \\
75 \% \text { out of 39 } \\
\text { teachers }\end{array}$ \\
\hline
\end{tabular}

Data of teachers'performance in

In case success indicators are not achieved at specified time, research must go on with next cycle.

\section{Data Collecting Technique}

composing evaluation instrument was collected by questioner distribution and observation. Before the treatment given, the researcher measure the performance by giving them the questioners. When treatments were given in cycle I and II, the 
questioners then distributed again. The observation made to check the consistency between criterion of evaluation instrumen and intregrated lesson plan documents. The presence of other supervisor when the workshop in progress meant to be peer observer. To maintain comfortable atmosphere during the process, the research only empower one supervisor as observer. Psycological pressure may cause the teachers work underpressure and come up with lower output

\section{Conceptual and Operational}

\section{Definition}

a. Conceptual Defintion

1) Workshop Implementation

Workshop is a part of teachers'development competency inside a school unit, a media where teachers discuss their profession problems with a good atmosphere related to continual development, more accentuation on planning, acting, and evaluating the progress made by the students, and produce document of instrument both evaluation and character integrated lesson plan.

2) Teachers'performance in Composing Evaluation Instrument of Character Education
Desigining and producing evaluation instrument document of character education which can be used as criterion toward standard and basic competency being instructed.

\section{3) Performance of Composing}

\section{Integrated Character Lesson Plan}

Desigining and producing integrated character value lesson plan, descended from syllabus which embodied into instructional process.

\section{b. Operational Definition}

\section{1) Workshop Implementation}

A full of spirit of activity held in SMA TMI Roudlatul Qur'an as an attempt in developing teachers'performance to produce evaluation instrument of character education and an integrated character value lesson plan which later converted to a performance predicate

\section{2) Teachers'performance in Composing} Evaluation Instrument of Character

\section{Education}

Predicate obtained by teachers of SMA TMI Roudlatul Qur'an as a measurement and teachers'performance of producing evaluation instrument document for character education by considering 
domain, indicators, scale, design, study, revision, and result of analysis.

\section{3) Performance of Composing}

\section{Integrated Character Lesson Plan}

Predicate obtained by teachers of SMA TMI Roudlatul Qur'an as a measurement of teachers'performance in composing and producing character integrated lesson plan which covers the instruction sintax, pre activity, main activity, and closing and supporting related files.

\section{Technique of Data Analysis}

Data quantitative analized with percentage and interpreted to describe the result of the research. Every finding must coorelate to the theory which suppot practical situation to improve instruction process. To maintain data validity, a member check ought to be conducte, (Moleong, 1989). A triangulation is also necessary to make sure whether what is understood by the researcher is also the same with peer or other informan related to observed object, (Bungin, 2003). A crosschecking to peer on what findings will legimite the accuracy of the conclusion.

\section{Result and Discussion \\ 1. Result}

\section{a. Workshop Implementation}

How well the implementation of workshop can be found on the picture below here.

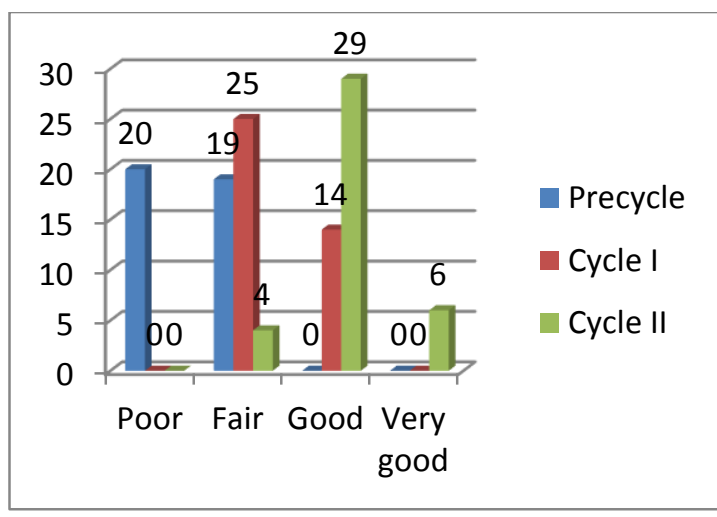

Picture1. Workshop Implementation

The picture clearly explain that there were 20 poor scoring, 19 fair scoring on workshop implementation at cycle I. When cycle I treatment done, no more poor scoring and turn to 25 fair scoring, and 14 good scoring. At cycle II, fair scoring left only 4 , good scoring turn to 29 , and very good scoring reached 6 . It means that workshop implementation became good to as many 29 teachers.

\section{b.Teachers'performance in Composing Evaluation Instrument of Character Education}

Teachers'performance in composing character education evaluation instrument can be seen on the picture below. 


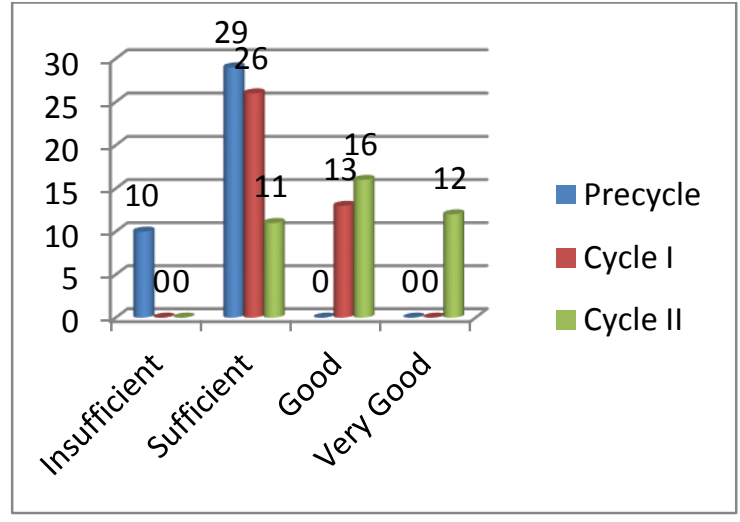

Picture 2. Teachers'performance in composing character education evaluation instrument

The picture above tells that, earlier there were 10 teachers with insufficient predicate, 29 with sufficient predicate. After treatment of cycle I done, there were 26 sufficient teachers and 13 good teachers. At last, cycle II, sufficient teachers left to 11, good teachers reached 16 , and very good teachers turn into 12 .

\section{c. Performance of Composing Integrated \\ Character Lesson Plan}

The teachers'performance of composing integrated character lesson plan can be described as follows.

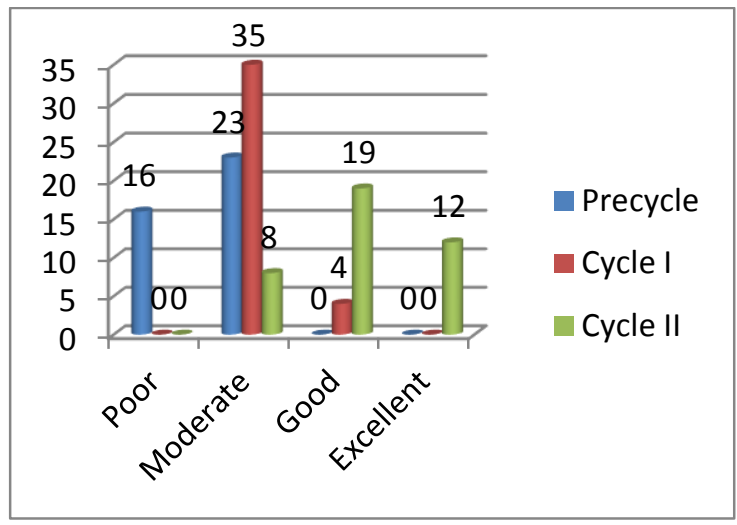

Picture 3. Teachers'performance of Composing Integrated Character Lesson Plan
Earlier data shows there were 16 teachers with poor performance, 23 teachers with moderate performance, and no one with good performance. After cycle I, better change occured, 35 teachers became moderate and 4 teachers became good. At cycle II, the performance improve much better, moderate performance left 8 teachers, good performance reached 19, and excellent performance turned into 12 teachers.

\section{Discussion}

\section{a. Workshop Implementation}

Workshop implementation mostly done with brainstorming strategy. Although the technique took turn between group and individual technique, the supervisor empower teachers knowledge to boost total participation. It was effective to apply explanatory, interactive question and answer, discussion, and simulation. Brainstorming was carried out to deal with some problems demand on intensive solution. The shortcomings of facilitator can be overcome by the applying this technique. Some of the teachers who sent to attend local desimination of character education recieved better understanding, but still fail to share what they got to others. Brainstorming was then reinforced 
by discussion to further explore possible solution under the same perception.

The demand of construction and improvement of human resource at this context is something imperative to notice.

The advance of science and technology has became a big challenge for education continuity. That's why, every school must be responsive toward the rapid change in any life field. The global development of education information insists on teachers to think globally and at the same time upgrade their performance ceaselessly. As the pioneers of education success, the rapid change of the world, they have to keep up with the progress. Mastering current issues will keep them up dated and henceby will be able to provide the latest information during instructinal process to the students. One of the current issues at this moment is character education itself. Even the whole world sense that a decrease of character now occupying youth.

Variation of implementation method during workshop has made better involvement from the participants. This condition brought up a good phenomena of workshop. The point of measurement such as, spirit, openness, healthy competition, consistent continuity, the same atmosphere sympthom, attention focus on the workshop goals, the use of financial support to achieve the workshop objectives showed better predicate from time to time.

As an independent program, the workshop was financed by SMA TMI Roudlatul Qur'an alone, for sure, the program deserve a recognition and appreciation. The program was organized based on what is needed by the teachers and the school. The program was one the ways to achieve vision and strategic mission, and an innovative movement of attempting the quality development of education at SMA TMI Roudlatul Qur'an. The quality commitment is to improve classroom quality practice and education quality, instruction method commitment is to establish an effective instruction to promote learning and improve final exam result, and the system commitment is to support the continous development.

\section{b. Teachers'performance in Composing Evaluation Instrument of Character Education}

The performance of teachers to compose the character education evaluation instrument must follow the validity and reliability criterion. It gets better when the validity and reliability instrument meet some requirements. An instrument becomes valid when it measures what has to be measured. The analogy of this concept for example, a tape 
meter can measure length accurately, but it wont provide sufficient information to measure weight. Which is why, the instrument is valid when there is equivalency between real data and observed object. An instrument also need to be reliable. It must have consistency in providing the same data.A valid and reliable instrument are absolute condition to produce valid and reliable research data(Sugiyono, 2009).

To meet valid and reliable aspect is not an easy matter. On daily basis, validity and reliabilty of an instrument are acceptable by applying construct and content validity. It means that the teachers don't have to run empirical validity. Construct validity initiated by constructing spesification table of instrument, followed by mapping aspects and indicators which later become items to measure the variable. When items of value character evaluation instrument go in accordance with aspect and variabel, it can be claimed that the instrument is construct validated. It has clear relation to the definition of character itself. Character is an identity owned by object or individu. The identity is genuine and root in the personality, it also becomes an engine which propel of someone act, behave, utter, and respon to something, (Hermawan Kertajaya, 2010). The

definition must become aspect and indicator the variable to be valid.

Content validity meant that items exist in the instrument measure relevant materials. When items have strong relation with materials to be measured then it has good content validity.

In the beggining of the workshop, there were many teachers who found difficulties to map the variable of value character and develop the indicators. As time progressed, they had the chance to browse related issue and found some valuable information from many resources to develop the indicator. Every character value must provide sufficient explanation in relation with the definition and unsure involved. The affective domain (from level A1 to A5) can be adjusted with the indicator which form the domain and aspect. This support the notion that "Evaluasi adalah proses untuk melihat apakah perencanaan yang sedang di bangun berhasil, sesuai dengan harapan awal atau tidak"(Mardia Hayati, 2009)Revision allows teachers to perform analysis and improvement to reach better result. 
c. Performance of Composing Integrated Character Lesson Plan

Through discussion and opinion exchange, there were some ways to implement character education. Value of character education, apart from the integration in the curriculum, can also be integrated in daily routine activity, such as prayers before classroom practice, starting class right on time, neatness and cleanliness of school environment and uniform, etc. This is relevant to an opinion "Kegiatan rutin merupakan kegiatan yang dilakukan anak didik secara terus menerus dan konsisten setiap saat."(Daryanto dan Surya Tri Darmiatun, 2013). Some example of this routine are aniversary of important days, cleanliness check (nail, ear, hair, etc), prayers together, greeting each others.

Integration of value character at routine activity of school is to cultivate the values in any kind of routine activity which leads to positive habituation of all school community, both students and teachers.For religious value ( attitude and behaviour to do based on the belief) can be integrated with praying together, being a role model and many more with behavior sample.

\section{Conclusion and Suggestion}

\section{Conclusion}

Finally, the researcher can conclude that teachers'performance of SMA TMI Roudlatul Qur'an in composing character education evaluation instrument and character integrated lesson plan impoved well through workshop. Findings support the conclusion are:

1) There were 20 poor scoring, 19 fair scoring on workshop implementation at cycle I. When cycle I treatment done, no more poor scoring and turn to 25 fair scoring, and 14 good scoring. At cycle II, fair scoring left only 4, good scoring turn to 29 , and very good scoring reached 6 . It means that workshop implementation became good.

2) There were 10 teachers with insufficient predicate, 29 with sufficient predicate. After treatment of cycle I done, there were 26 sufficient teachers and 13 good teachers. At last, cycle II, sufficient teachers left to 11 , good teachers reached 16, and very good teachers turn into 12

3) There were 16 teachers with poor performance, 23 teachers with moderate performance, and no one with good performance. After cycle I, better change occured, 35 teachers became moderate and 4 teachers became good. At cycle II, the 
performance improve much better, moderate performance left 8 teachers, good performance reached 19, and excellent performance turned into 12 teachers.

\section{Sugestion}

Several things are suggested based on the conclusion:

1) Implementing intensif workshop, at least in the beggining of every academic year

2) Implementing directive approach in the beggining of the workshop and collaborative approach with discussion or brainstorming to get best alternative solution

3) Character value integrated in school routine activity which lead to positive habituation of all school community, both teachers and staff.

\section{E. References}

Bungin, Burhan. (2003).Analisis Data Penelitian Kualitatif: Pemahaman Filosofis dan Metodologis keArah Penguasaan Model Aplikasi. Jakarta: Rajagrafindo Persada. Daryanto dan Surya Tri Darmiatun, Pendidikan Karakter di Sekolah. Yogyakarta: Gava Media.

Hermawan Kertajaya. (2010).Grow with Character: The Model Marketing. Jakarta: PT. Gramedia Pustaka Utama.

Kemmis, S. \& McTaggart, R. (1983).The Action Research Planner. 3rd ed. Victoria, Australia: Deakin University.

Mardia Hayati. (2009). Desain Pembelajaran, Pekanbaru, Yayasan Pustaka Riau.

Moleong, Lexy. J. (1989).Metode Penelitian Kualitatif. Bandung: Remaja Rosdakarya.

Sugiyono(2010). Metode Penelitian Administrasi. Bandung : Alfabeta. 